\title{
Miego hipoventiliacijos sindromas
}

\author{
Guoda Pilkauskaitè, Skaidrius Miliauskas \\ LSMU MA Pulmonologijos ir imunologijos klinika
}

\begin{abstract}
Reikšminiai žodžiai: miego hipoventiliacijos sindromas, hipoventiliacija, hiperkapnija.
Santrauka. Miego hipoventiliacijos sindromas pasireiškia padidejjusiu anglies dvideginio kiekiu arteriniame kraujyje miegant ir dažnai yra lydimas kraujo įsotinimo deguonimi sumažèjimo. Dažniausi simptomai: rytiniai galvos skausmai, nepailsẻjimas miegant, mieguistumas dieną. Ankstyva diagnostika ir efektyvus gydymas padeda išvengti sunkių komplikacijų.
\end{abstract}

Terminas hipoventiliacija reiškia nepakankamą ventiliaciją, kai sutrinka deguonies ir anglies dvideginio apykaita. Hipoventiliaciją gali sąlygoti ịvairios būklès. Tarptautinejje ligų klasifikacijoje TLK-10 AM yra kodas G47.33 - miego hipoventiliacijos sindromas [1]. Sio sindromo pavadinimas rodo, kad kalbama apie hipoventiliaciją, kuri atsiranda būtent miego metu. Miego sąlygotas hipoventilicijos sindromas kartu su obstrukcine miego apneja ir centrine miego apnejja priskiriami kvèpavimo sutrikimams miego metu.

Miego hipoventiliacijos sindromui būdingas miegant padidejęs anglies dvideginio kiekis arteriniame kraujyje $\left(\mathrm{PaCO}_{2}>45 \mathrm{~mm} \mathrm{Hg}\right)$ arba neproporcingai padidèjęs $\mathrm{PaCO}_{2}$ kiekis palyginti su jo kiekiu nemiegant [2]. Be to, miegant kraujo izsotinimas deguonimi $\left(\mathrm{SpO}_{2}\right)$ būna mažesnis nei 90 proc. daugiau nei 5 minutes su mažiausiu $\mathrm{SpO}_{2}$ $<85$ proc. [3]. Būklès, kurios lemia miego hipoventiliacijos sindromą, yra labai ịvairios: kvėpavimo sistemos ligos, kaip antai: lètinè obstrukcinè plaučių liga (LOPL), cistiné fibrozè, ìvairios plaučiu parenchimos ligos, centrinè ir obstrukcinè miego apnejja. Miego hipoventiliaciją sukelia ir

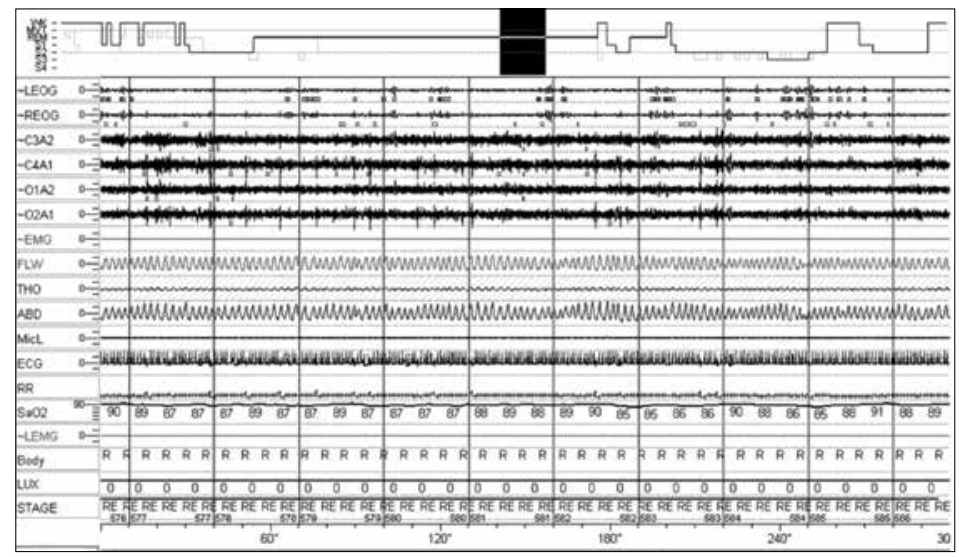

Pav. Paciento, kuriam patvirtintas miego hipoventiliacijos sindromas, polisomnograma

5 min. atkarpoje fiksuotas deguonies kiekio $\left(\mathrm{SaO}_{2}\right)$ sumažejimas paradoksinio (REM) miego metu. Kiti registruoti parametrai be patologinių pokyčių.

LEOG, REOG - okulograma; C3M2, C4M1, O1M2, O2M1 - encefalograma; EMG - smakr raumenų miograma; FLW - oro srauto kreivė; THO, ABD - krūtinès ir pilvo judesių kreivės; MicL - mikrofonas; ECG - elektrokardiograma; RR - širdies susitraukimų dažnis; LEMG - kojų raumenų tonusas; Body $(R)$ - kūno padètis $(R$ - pacientas guli ant dešiniojo šono)). nutukimo hipoventiliacijos sindromas, kuris neretai būna lydimas obstrukcinès miego apnèjos. Yra nemažai igimtų ligų, kurios pasireiškia miego hipoventiliacija, kartais net pavojinga gyvybei. Igimto centrinès alveolinès hipoventiliacijos sindromo atveju gyvybei pavojingos apnèjos su hipoventiliacija pastebimos jau pirmaisiais gyvenimo mènesiais. Jis pasireiškia 1 iš 200 tūkst. naujagimiu ir negydomas baigiasi mirtimi. Sergantys Arnold-Chiari malformacija ar Prader-Willi sindromu sulaukia vyresnio amžiaus. Miego hipoventiliacijos, o vèliau ir lètinio kvėpavimo nepakankamumo priežastis gali būti ịvairios igimtos ar igytos krūtinès ląstos deformacijos. Daugybe ịvairiausių neurologinių ligų sąlygoja šio sindromo išsivystymą. Nereikètų pamiršti, kad ir smegenų insultas bei įvairūs centrinès nervų sistemos augliai gali pasireikšti kvèpavimo reguliacijos sutrikimais. Be to, kai kurie preparatai, ypač opoidai, pasižymi kvėpavimo funkciją slopinančiu poveikiu.

Bet kurios priežasties sukeliamas kvėpavimo nepakankamumas miegant, pasireiškiantis hipoksemija ir (arba) hiperkapnija gali pasunkèti dèl fiziologinių procesų, ypač paradoksinio (REM) miego laiku ịvykus raumenų atonijai, kai kvẻpavimo darbą reguliuoja diafragma, sumažèja minutinè ventiliacija ir kvėpuojamasis tūris, dèl ko hipoksemija ir (arba) hiperkapnija dar labiau padideja. Gelbstintysis mechanizmas, gerinantis ventiliaciją, yra atsirandantys žadinimo (mikroprabudimo) ar atsibudimo epizodai, kurie sąlygoja miego fragmentaciją, nuovargi, o vẻliau ir kognityvinius sutrikimus [4]. Didejja plaučių kraujagyslių pasipriešinimas, dèl to gali išsivystyti lètinès plautinè širdis. Ankstyva diagnostika ir tinkamas gydymas yra būtini norint išvengti pavojingu komplikacijų [5].

\section{DIAGNOSTIKA}

Dažniausi miego hipoventiliacijos simptomai yra rytiniai galvos skausmai, nepailsèjimas miegant, mieguistumas dieną, besikartojančios kvėpavimo takų ligos, lètinės plautinės širdies požymiai.

Esant minètiems simptomams, reikètų apžiūrèti pacientą atkreipiant dèmesị, ar nèra lètinio kvėpavimo nepakankamumo požymių, atlikti auskultaciją, pamatuoti kraujo ìsotinimą deguonimi $\left(\mathrm{SpO}_{2}\right)$ pulsoksimetru. Šie objektyvaus tyrimo duomenys gali nerodyti jokių patologinių pokyčių. 
1 lentelè. Nepakankamos ventiliacijos rizika (pagal 7)

\begin{tabular}{|c|c|}
\hline Rizika & Priežastis \\
\hline Didelè & $\begin{array}{l}\text { Ivairios nervụ-raumenų ligos } \\
\text { Aukštas nugaros smegenų pažeidimas (virš C5) } \\
\text { Igimta skoliozè kartu su neurofibromatoze ar osteogene- } \\
\text { sis imperfecta }\end{array}$ \\
\hline Vidutinè & $\begin{array}{l}\text { Patologinis nutukimas } \\
\text { Ankstyva skoliozè (iki } 5 \text { metų amžiaus) ir gyvybinès } \\
\text { talpos sumažejimas }<50 \text { proc. būtinojo dydžio } \\
\text { II tipo spinalinè raumenų atrofija } \\
\text { Sanklotos (angl. overlap) sindromas, kai } \mathrm{FEV}_{1}<1,51\end{array}$ \\
\hline Maža & $\begin{array}{l}\text { III tipo spinalinė raumenų atrofija } \\
\text { Pacientai, kuriems yra plaučių emfizema ir taikoma } \\
\text { nuolatinè deguonies terapija (rizika padideja, esant } \\
\text { galutinei ligos stadijai) } \\
\text { Intersticinè plaučių liga (rizika didejja, esant galutinei } \\
\text { ligos stadijai) }\end{array}$ \\
\hline
\end{tabular}

Reikètų atlikti plaučių funkcijos tyrimus (spirometriją, ìvertinant forsuoto iškvejpimo tūrị per pirmąją sekundę $\left(\mathrm{FEV}_{1}\right)$, gyvybinę plaučių talpą $(\mathrm{VC})$, išmatuoti kvèpavimo raumenų jègą), krūtinès ląstos rentgenografiją ir arterinio kraujo dujų tyrimą. Kadangi pacientams hipoventiliacija pasireiškia tik miego metu, būtini tyrimai, kuriais registruojama ventiliacija naktic. Tai visos nakties oksimetrija, perkutaninis $\mathrm{CO}_{2}$ matavimas, poligrafija (matuojant $\mathrm{SpO}_{2}$, oro srautą ir krūtinès judesius) [6]. Tiksliausias diagnostikos metodas - visos nakties polisomnografija.

Polisomnografija - tai tyrimas, kurio metu rašoma encefalograma (padedanti nustatyti ne tik kada pacientas miega, bet ir kokia yra miego stadija), elektrokardiograma, $\mathrm{SpO}_{2}$ (dar naudingiau, jeigu išmatuojamas ir perkutaninis $\left.\mathrm{CO}_{2}\right)^{2}$, oro srauto, krūtinès ir pilvo judesių kreivès, kojų raumenų tonusas, kūno padètis (pav.). Polisomnografija padeda atskirti miego hipoventiliacjos sindromą nuo kitų kvèpavimo sutrikimu miegant.

\section{GYDYMAS}

Prieš pradedant gydyti pacientus, pirmiausia reikètų kuo tiksliau išsiaiškinti miego hipoventiliacijos priežastị ir ją koreguoti. A. K. Simonds naujausiame kvèpavimo sutrikimu miegant vadovèlyje siūlo tokị pacientų priežiūros planą [7]:

- naktinès hipoventiliacijos rizikos ịvertinimas išsiaiškinant didelès rizikos atvejus (1 lentelè);

- nuolatinis būklès vertinimas, atliekant miego tyrimus, kartu vertinant ir $\mathrm{PaCO}_{2}$;

- būklių, kurias galima keisti, korekcija, pvz., nutukusiems pacientams - svorio mažinimas;

- pradèti taikyti ventiliaciją pacientams, sergantiems nervu-raumenu ar krūtinès ląstos ligomis, kai pasireiškia nakties hipoventiliacijos simptomų;

- gydyti deguonimi, jei $\mathrm{SaO}_{2}<90$ proc., esant normaliam $\mathrm{PaCO}_{2}$;

- stebejjimas, kad būtu užtikrinta adekvati ventiliacija. Visi gydymo metodai pateikti 2 lentelèje. Reikètų atkreipti dèmesĭ, kad gydymas deguonimi gali būti ir žalingas, nes gali pagilinti hiperkapniją, sukelti komą ar net mirtį. Nuolatinio teigiamo slègio ventiliacija (angl. continuous positive airway pressure, CPAP) - pirmaeilis gydymo metodas tik tiems pacientams, kuriems nustatyti kvejpavimo sutrikimai miegant, bet netinkamas, pvz., nervų-raumenų sistemos ligų sąlygotai hipoventiliacijai gydyti. Dažniausiai efektyviai gydoma dviejų slègių ventiliacija (BiLevel), daugumai pacientu ji veiksminga ventiliuojant pro nosies kaukę.

Tam, kad būtu užtikrinta tinkama alveolinès venti-
2 lentelè. Miego hipoventiliacijos gydymo metodai (pagal 6)

\begin{tabular}{ll}
\hline $\begin{array}{l}\text { Gydymo } \\
\text { metodas }\end{array}$ & Komentaras \\
\hline $\begin{array}{l}\text { Gydymas } \\
\text { deguonimi }\end{array}$ & $\begin{array}{l}\text { Tinka, kai ventiliacijos/perfuzijos sutrikimas sąlygoja } \\
\text { hipoksemiją (pvz., hipoventiliacija kartu su plaučių } \\
\text { parenchimos ligomis, bet skiriamas deguonis gali ir } \\
\text { pagilinti hipoventiliaciją) }\end{array}$ \\
\hline $\begin{array}{l}\text { CPAP } \\
\text { ventiliacija }\end{array}$ & $\begin{array}{l}\text { Kada viršutinių kvėpavimo taku funkcijos sutrikimas } \\
\text { yra miego metu atsirandančios hiperkapnijos prie- } \\
\text { žastis (pvz., kai kuriems pacientams esant nutukimo } \\
\text { hipoventiliacijos sindromui, sanklotos (angl. overlap) } \\
\text { sindromui, skoliozei) }\end{array}$ \\
\hline $\begin{array}{l}\text { BiLevel } \\
\text { ventiliacija }\end{array}$ & $\begin{array}{l}\text { Dažniausiai skiriama miego hipoventiliacijai gydyti, } \\
\text { pagerina objektyvius rodiklius ir pacientų savijautą }\end{array}$ \\
\hline $\begin{array}{l}\text { Tūrinė } \\
\text { neinvazinė } \\
\text { plaučių } \\
\text { ventiliacija }\end{array}$ & $\begin{array}{l}\text { Dažniausiai skiriama, kai BiLevel ventiliacija neefek- } \\
\text { tyvi. Taikoma, kai reikia ventiliuoti pro tracheostomą } \\
\text { arba būtina nepertraukiama ventiliacija visą parą }\end{array}$ \\
\hline
\end{tabular}

liacijos kontrolè, pakanka paprastesnių tyrimo metodų, pvz., pulsoksimetrijos ir $\mathrm{PaCO}_{2}$ matavimo. Šiuolaikiniai ventiliatoriai turi atminties blokus, kuriuose fiksuojamas ventiliatoriaus darbas ir paciento ventiliacijos rodikliai. Tai padeda gydytojui spręsti apie ventiliacijos efektyvumą [7].

Žinoma, kad alkoholis ir kai kurie vaistai (benzodiazepinai, barbitūratai, opioidai) slopina kvėpavimo funkciją, ir miego hipoventiliacijos sindromas yra kontraindikacija juos vartoti, nes gali ištikti koma, o kartais net mirtis [8].

Reikètų turèti omenyje, kad miego hipoventiliacija gali išnykti tinkamai koreguojant ją sukèlusią priežastį. Kyla klausimas, ar tikslinga specialiomis priemonemis koreguoti miego hipoventiliacijos sindromą. İrodyta, kad nutukusiems pacientams taikant CPAP ar neinvazinę ventiliaciją prieš bariatrines operacijas sumažinama anestezijos keliama rizika, pagerejja žaizdų gijimas [7]. Pacientus, kuriems nustatyta kifoskoliozè, sukelianti miego hipoventiliaciją, būtina pradèti gydyti kol dar nèra lètinio kvèpavimo nepakankamumo [9]. Dažnam šių pacientu gydymo deguonimi nepakanka. İrodyta, kad pacientų, kurie gydomi neinvazine plaučiu ventiliacija namų sąlygomis, išgyvenamumas yra geresnis nei tų, kuriems taikomas nuolatinis gydymas deguonimi $[10,11]$.

Nors iki šiol Lietuvoje Valstybiné ligonių kasa nekompensuoja miego hipoventiliacijos sindromo gydymo išlaidų, reikètų žinoti, kad simptominiams pacientams galima padèti: siųsti i specializuotus miego tyrimų centrus, kur bus patikslinta diagnozè ir parinktas gydymo metodas.

\section{SLEEP-RELATED HYPOVENTILATION SYNDROME}

GUODA PILKAUSKAITE, SKAIDRIUS MILIAUSKAS LSMU MA DEPARTMENT OF PULMONOLOGY AND IMMUNOLOGY

Keywords: sleep-related hypoventilation syndrome, hypoventilation, hypercapnia. Summary. Sleep-related hypoventilation syndrome is characterized by elevated $\mathrm{PaCO}$ during sleep usually accompanied by arterial oxygen desaturation. The most frequent symptoms are morning headache, unrefreshing sleep, daytime sleepiness. Early diagnosis and effective treatment prevents severe complications.

\section{LITERATŪRA}

1. TLK-10 AM. Prieiga per www.vlk.It

2. Muir JF. Hypoventilation syndromes. ERS handbook of respiratory medicine. Ed. Palange P, Somonds AK. 2010; 414-416.

3. Caples SM, et al. Central sleep apnea, hypoventilation syndromes and periodic breathng disorders. Sleep apnea. 2006; 180-191.

4. Be Backer WA. Central sleep apnoea, pathogenesis and treatment: an overview and perspective. Eur Res J. 1995;8:1372-1383. 